\title{
Irfani
}

ISSN 1907-0969 E ISSN 2442-8272

Volume 16 Nomor 1 Juni 2020

Halaman 9-25

http://journal.iaingorontalo.ac.id/index.php/ir

\section{MEDIA REALIA DALAM PEMBELAJARAN SAINS ANAK USIA 5-6 TAHUN}

\author{
Sitti Rahmawati Talango \\ IAIN Sultan Amai Gorontalo \\ email: sititalango@iaingorontalo.ac.id
}

\begin{abstract}
ABSTRAK
Pemanfaatan media realia dalam kegiatan pembelajaran sains untuk anak usia 5-6 tahun, tidak terlepas dari sifat anak dalam mempelajari sesuatu melalui benda-benda konkrit, sehingga pengalaman belajarnya menjadi bermakna. Pembelajaran sains pada anak usia dini menekankan pada proses menemukan dan melakukan eksperimen sederhana, melalui refleksi dari temuannya. Anak-anak pada tahap berpikir pra opersiaonal, yaitu pada rentang usia 2-7 tahun, memiliki karakteristik berpikir egosentris dan simbolis dapat mengalami pembelajaran langsung dengan menggunakan media realia. Media realia sebagai objek nyata dapat mewakili kemampuan berpikir simbolik pada tahap pra-operasional anak. Maka guru akan mampu menjelaskan hal-hal yang bersifat abstrak, secara langsung.

Kata Kunci : Media realia, Pembelajaran Sains, Anak Usia 5-6 Tahun.

\section{PENDAHULUAN}

Segala bentuk kehidupan dan peristiwa merupakan manifestasi dari fenomena alam, dan cara Tuhan menunjukkan eksistensi manusia sebagai makhluk yang senantiasa menggunakan akalnya. Keberadaan manusia sebagai makhluk yang berakal, menghasilkan banyak kajian ilmu pengetahuan, baik yang berhubungan dengan alam maupun maupun makhluk hidup lainnya.

Kajian keilmuan tentang sains berkaitan dengan proses sepanjang hidup manusia. Hal ini dikarenakan, seluruh kegiatan manusia adalah inti dari konsep sains itu sendiri, yaitu bagian dari fenomena alam yang kemudian dapat dipelajari prosesnya secara sistematis. Contoh sederhana dari konsep sain yang dapat kita pelajari dalam kehidupan sehari-hari ialah, mengapa pakaian yang basah dapat kering
\end{abstract}




\section{Irfani}

ISSN 1907-0969 E ISSN 2442-8272

Volume 16 Nomor 1 Juni 2020

Halaman 9-25

http://journal.iaingorontalo.ac.id/index.php/ir

jika dijemur dibawah panas matahari?, mengapa terjadi pelangi?, mengapa makhluk hidup berkembang biak? dan masih banyak fenomena alam lainnya.

Pertanyaan dan peristiwa tersebut sering dilontarkan oleh anak-anak, khususnya anak usia dini, sebagai bagian dari proses berpikir mereka. Mengingat perkembangan kemampuan berpikir anak di usia di usia dini, berada pada tahap berpikir konkrit. Anak memerlukan penjelasan atas pertanyaan tersebut. Namun, seringkali orang tua maupun guru mengalami kesulitan dalam memberikan penjelasan yang mudah diterima oleh anak-anak. Tentu saja saja hal ini akan memberikan dampak lain bagi kehidupan anak. Anak dapat mencari informasi dari sumber yang salah, sehingga mendapatkan informasi yang keliru dan tidak sistematis, terlebih anak tidak memiliki kepedulian terhadap lingkungan sekitarnya, disebabkan kurangnya minat anak dalam pembelajaran sains, yang pada hakikatnya membahas tentang alam dan fenomenanya.

Perkembangan sains yang semakin kompleks dan pesat tidak memungkinkan guru menginformasikan semua fakta dan konsep pada peserta didik. Namun pembelajaran sains merupakan interaksi langsung antara anak dengan lingkungan sekitarnya. Dengan demikian pembelajaran sains perlu mengutamakan peran anak dalam kegiatan belajar mengajar. Diperlukan suatu pembelajaran yang dapat memotivasi anak untuk mempersiapkan diri belajar secara utuh dan tidak semata-mata berorientasi pada penguasaan konsep. Kegiatan pembelajaran itu tidak hanya diarahkan untuk membuat anak mengusai sejumlah konsep pengetahuan melainkan juga diarahkan untuk mengembangkan sikap, potensi yang optimal, terutama menumbuhkan minat dalam pembelajaran sains. Namun hal ini berbeda dengan riset yang dikemukakan oleh Kementerian Pendidikan dan Kebudayaan (KEMENDIKBUD).

Kementerian Pendidikan dan Kebudayaan (Kemendikbud) merilis pencapaian nilai Programme for International Student Assessment (PISA), PISA merupakan sistem ujian yang diinisasi oleh Organisation for Economic Cooperation and Development (OECD), untuk mengevaluasi sistem pendidikan dari 72 negara di seluruh dunia. Setiap tiga tahun, dan tahun 2015 fokus temanya adalah kompetensi sains. Berdasarkan riset yang dilakukan, waktu pembelajaran sains seluruh negara yang tergabung dalam $O E C D$ menunjukkan $94 \%$ murid rata-rata mengikuti satu mata pelajaran sains dalam seminggu. Namun, di Indonesia, sejumlah $4 \%$ murid tercatat sama sekali tidak dituntut untuk mengikuti mata pelajaran sains. Ketidakharusan 


\section{Irfani}

ISSN 1907-0969 E ISSN 2442-8272

Volume 16 Nomor 1 Juni 2020

Halaman 9-25

http://journal.iaingorontalo.ac.id/index.php/ir

untuk mengikuti mata pelajaran sains lebih besar lima persen di sekolah yang kurang beruntung, dibandingkan di sekolah yang lebih maju. ${ }^{1}$

Hal ini mengindikasikan bahwa mata pelajaran sains di Indonesia berbanding terbalik dalam prioritasnya, indikasi ini ditunjukkan dengan data di sekolah kurang beruntung yang mencapai 9\%, ketidakharusan dalam mata pelajaran sains, bisa jadi disebabkan kurangnya kesiapan sekolah dalam memfasilitasi pembelajaran sains di sekolah, yang memicu minat anak dalam kegiatan pembelajaran sains. Jika ditinjau hakikat pengembangan sains di TK adalah kegiatan belajar sambil bermain yang menyenangkan dan menarik melalui pengamatan, penyelidikan dan percobaan untuk mencari tahu atau menemukan jawaban tentang segala sesuatu yang ada di dunia sekitar. Hal ini memiliki kaitan dengan karakteristik kemampuan kognitif anak pada tahap praoperasional. Tahap yang dimaksudkan ialah anak mampu mengkombinasi dan mentransformasi berbagai informasi ${ }^{2}$. Dengan demikian guru diharapkan dapat memfasilitasi, menumbuhkan minat anak, dan memberikan kesempatan seluas-luasnya pada anak untuk mengeksplorasi pengetahuannya melalui kegiatan pembelajaran sains sederhana.

Proses pembelajaran sains yang akan dilaksanakan, memerlukan identifikasi yang tepat dari guru untuk mengetahui minat dan bakat yang dimiliki anak, seperti yang diungkapkan oleh Bredekamp, bahwa para pengajar juga harus mencermati dan menyimak perbedaan antara keterampilan dan minat anak. ${ }^{3}$ Untuk itu, guru atau pendidik perlu menciptakan inovasi dalam pembelajaran sains sehingga pembelajaran sains menjadi menyenangkan dan anak menaruh minat terhadap pelajaran tersebut. Selain materinya yang harus dimodifikasi, keterampilan proses sains juga perlu disesuaikan berdasarkan tahapan perkembangan anak, dengan memperhatikan bentuk metode dan media yang digunakan. Salah satu bentuk inovasi yang dapat guru lakukan yaitu penggunaan media pembelajaran yang menarik dan sesuai dengan tujuan pembelajaran yang ingin dicapai.

\footnotetext{
${ }^{1}$ Kemdikbud, Peringkat dan Capaian PISA mengalami Peningkatan. 2016. https://www.kemdikbud.go.id/main/blog/2016/12/peringkat-dan-capaian-pisa-indonesia-mengalamipeningkatan[ 10 September 2018

${ }^{2}$ Khadijah, Pengembangan Kognitif anak Usia Dini, (IKAPI Medan :Perdana Publishing), hlm.38

${ }^{3}$ Pamela. A. Coughlin et,al, Menciptakan Kelas yang Berpusat Pada Anak 3-5 Tahun (Washington DC: Children's Resources International, Inc, 1997), hlm.9
} 


\section{Irfani}

ISSN 1907-0969 E ISSN 2442-8272

Volume 16 Nomor 1 Juni 2020

Halaman 9-25

http://journal.iaingorontalo.ac.id/index.php/ir

Media pembelajaran merupakan segala sesuatu yang dapat digunakan dalam proses belajar untu menyalurkan pesan, dari guru kepada peserta didik, sehingga terjadi interaksi yang efektif dan efisien antara keduanya dalam proses pembelajaran. Berdasarkan Sumbernya media pembelajaran, dapat berasal dari manusia, media pendidikan seperti sarana pendidikan, media massa, buku dan lingkungan. Lingkungan sebagai salah satu sumber belajar media, memiliki banyak bentuk media yang dapat digunakan. Salah satu media yang berasal dari sumber belajar lingkungan ialah media realia.

Media realia merupakan alat bantu visual dalam pendidikan yang berfungsi memberikan pengalaman langsung (direct experience) kepada anak. Realia ini merupakan model dan objek nyata dari suatu benda, seperti mata uang, tumbuhan, binatang, dsb. ${ }^{4}$ Media realia yang berasal dari sumber belajar lingkungan merupakn benda-benda real atau nyata yang dekat dengan anak, dan mudah untuk dijumpai anak karena berbentuk nyata. Dengan demikian penggunaan media tersebut dapat memberikan pengalaman nyata untuk anak. Banyak hal atau benda yang dapat dipilih, dikembangkan, dan dimanfaatkan sebagai media realia dalam proses pembelajaran sains.

Penggunaan media realia sebagai media pembelajaran sains pada anak usia dini tidak terlepas dari sifat dasar anak dalam mempelajari sesuatu melalui benda-benda konkrit sehingga pembelajaran menjadi bermakna bagi anak. Hal ini berbanding lurus dengan pernyataan dalam sebuah jurnal internasional berjudul "Benefits of Providing "Real Objects" and Materials in the Classroom." Dalam jurnal tersebut dijelaskan bahwa, penggunaan benda-benda nyata dapat menarik minat anak dalam pembelajaran, memfasilitasi anak untuk dapat memahami suatu konsep, dan meningkatkan kemampuan anak untuk menghubungkan aktivitas yang dilakukan di sekolah dengan dunia luar anak. Kegiatan ini berintegrasi dengan ketempilan proses sains dasar, sehingga memudahkan kegiatan belajar sains anak. Berdasarkan pemikiran tersebut, maka tulisan ini bertujuan untuk mengkaji penggunaan media realia dalam pembelajaran sains anak usia 5-6 tahun.

\footnotetext{
${ }^{4}$ Badru Zaman dan Cucu Eliyawati, Media Pembelajaran Anak Usia Dini, (Bandung: FIP UPI, 2010). hlm. 6

${ }^{5}$ Sallee Beneke \& Michaelene M. Ostrosky, Teachers' Views of the Efficacy of Incorporating the Project Approach Into Classroom Practice with Diverse Learners, Early Childhood Reasearch and Practice, (University of Illinois at Urbana-Champaign, 2009)
} 


\section{Irfani}

ISSN 1907-0969 E ISSN 2442-8272

Volume 16 Nomor 1 Juni 2020

Halaman 9-25

http://journal.iaingorontalo.ac.id/index.php/ir

\section{LANDASAN TEORI \\ Hakikat Sains}

Sains dikenal sebagai bentuk ilmu pasti karena prosesnya yang bersifat sistematis. Pendapat tentang sains sebagai ilmu pengetahuan yang sistematis, dikemukakan oleh Pamela dan Coughlin, yang menyatakan bahwa sains adalah sebuah batang pengetahuan yang terorganisir dengan baik mengenai dunia fisik dan alami. ${ }^{6}$ Maka, sains merupakan pengetahuan tentang alam beserta fenomena, dengan prosedur yang sistematis. Hal yang sama juga dikemukakan oleh Carin dan Sund dalam pendapatnya mengenai hakikat sains, "Science is the system of knowing about the universe through date are collected by observation and controlled experimentation". ${ }^{7}$ Berdasarkan pendapat tersebut, sains disebut sebagai sistem tentang pengetahuan alam semesta yang diperoleh melalui pengumpulan data dengan observasi dan eksperimen terkontrol. Definisi tersebut menegaskan bahwa pengetahuan tentang alam semesta dapat diperoleh dengan melakukan pengamatan dan percobaan yang merupakan kegiatan sistematis, sehingga diperoleh data-data yang dapat digunakan untuk menjelaskan hasil pengamatan dan percobaan yang berkaitan alam semesta.

Sains tidak hanya membahas tentang pengetahuan alam, namun juga semua aspek di dalamnya. Fieldman mengungkapkan bahwa,

"Science is not only knowledge about all the living and non living things in our environment; science is also a process-a way of finding out about the world, asking question, and learning how to solve problems". 8

Pernyataan Fieldman dapat diartikan secara bebas bahwa, sains tidak hanya pengetahuan yang berkaitan dengan kehidupan dalam lingkungan kita, tapi juga berarti sebagai sebuah proses-jalan dalam penemuan tentang dunia, mengajukan pertanyaan dan belajar bagaimana untuk mengatasi masalah. Pemahaman sains ini mengarah pada kompleksitas sains sebagai bagian dari ilmu pengetahuan yang mempelajari alam dan fenomenanya. Banyak hal yang bisa dikaji dalam sains itu sendiri.

${ }^{6}$ Pamela. A. Coughlin et,al, Menciptakan Kelas yang Berpusat Pada Anak 3-5 Tahun (Washington DC: Children's Resources International, Inc, 1997), hlm 327.

${ }^{7}$ Carin, Atur A and Robert B Sund, Teaching Science Through Discovery (Columbus Ohio: Merryl Publishing Company, 1989), hlm.4

${ }^{8}$ Jean R. Fieldman, A Survival Guide For The Preschool Teacher (USA : The center for Applied Research In Education, 1991),hlm.125 


\section{Irfani}

ISSN 1907-0969 E ISSN 2442-8272

Volume 16 Nomor 1 Juni 2020

Halaman 9-25

http://journal.iaingorontalo.ac.id/index.php/ir

Sains juga dapat menjadi sarana bagi anak dalam mengeksplorasi pengetahuan tentang lingkungannya. Hal tersebut diperkuat oleh pernyataan yang dikemukakan oleh B. Puckett dan Diffilly, bahwa "Science is not just a body of knowledge, it is a way of thinking, interesting, concrete materials to observe and explore encourage the natural of young children". 9 Pendapat tersebut memiliki arti bahwa sains tidak hanya sebuah kumpulan pengetahuan, sains merupakan sebuah cara alami untuk berpikir, menarik hati, mendorong keinginan anak secara alami untuk mengamati dan mengeskplorasi benda-benda nyata. Dengan demikian dalam sains banyak aktivitas yang dapat dilakukan seperti mengamati dan mengeksplorasi benda-benda yang nyata.

Anak dapat menggunakan seluruh indera yang dimiliki dalam sains, "Children can use their senses to touch, feel, taste, smell, and see. They can act on objects and observe what happens next." anak dapat menggunakan indera mereka untuk menyentuh, merasakan, mencium, dan melihat. Mereka dapat bertindak pada suatu objek dan mengamati apa yang akan terjadi selanjutnya. Hal ini tentu saja dapat mengembangkan sensorimotor anak.

Dari beberapa pendapat di atas, dapat dideskripsikan bahwa sains merupakan ilmu pengetahuan yang mengkaji fenomena alam dan lingkungan sekitar, dan segala aspeknya meliputi teori dan fakta, yang didapatkan secara sistematis.

\section{Pembelajaran Sains Anak Usia 5-6 Tahun \\ Pengertian Anak Usia Dini}

Anak usia dini merupakan kelompok anak yang memiliki pola pertumbuhan dan perkembangan khusus sesuai dengan tingkat pertumbuhan dan perkembangannya. Anak usia dini adalah anak yang berada pada rentang usia 0-8 tahun. $^{11}$ Usia ini dikenal dengan usia emas (golden age). Para ahli pendidikan juga berpendapat bahwa usia anak-anak adalah usia keemasan (the golden age).

Penelitian yang dilakukan oleh Osbon, White, dan Bloom menyatakan bahwa perkembangan intelektual atau kecerdasan anak pada usia 0-4 tahun mecapai 50\%, pada usia 8 tahun mencapai $80 \%$, dan $20 \%$ lagi berkembang hingga mencapai usia

\footnotetext{
${ }^{9}$ Margaret B. Puckett and Deborah Diffilly, Teaching Young Children An Introduction to the Early Childhood Prefession (New York: Thomson Delmar Lerning, 2004),hlm. 227

${ }^{10}$ Diane Trister, Dodge Colker, \& Cate Heroman, Creative Curricullum, (Washington DC: Teaching Stategies, Inc 2002), hlm. 381

${ }^{11}$ Diana Mutiah, Psikologi Bermain Anak Usia Dini (Jakarta: Kencana, 2010),hlm. 2
} 


\section{Irfani}

ISSN 1907-0969 E ISSN 2442-8272

Volume 16 Nomor 1 Juni 2020

Halaman 9-25

http://journal.iaingorontalo.ac.id/index.php/ir

18 tahun. $^{12}$ Oleh karena itu, usia dini merupakan rentang usia kritis atau periode sensitif yang memerlukan bentuk stimulasi optimal.

\section{Pembelajaran Sains Anak Usia Dini}

Pembelajaran sains bagi anak usia dini sangat penting, melalui pembelajaran sains didorong untuk mengenal dan memahami lingkungan sekitarnya. Pernyataan ini didukung oleh Brewer, yang mengemukakan bahwa:

"Science in early childhood education is encouraging children to explore their environment and reflect on their observation and discoveries". 13

Pernyataan tersebut kurang lebih bermakna bahwa sains dalam pendidikan anak usia dini, mendorong anak untuk mengeksplorasi lingkungannya serta merefleksikan hasil pengamatan dan penemuannya. Berdasarkan pendapat tersebut, dapat dipahami bahwa pembelajaran sains yang diberikan kepada anak sejak dini mendorong anak untuk belajar menemukan dan mendeskripsikan apa yang ditemukan.Allah Swt berfirman dalam Al-Quran Surat Al-Baqarah ayat 164, yang didalamnya mengajak kaum berfikir atas segala fenomena alam yang terjadi di sekitar kita. :

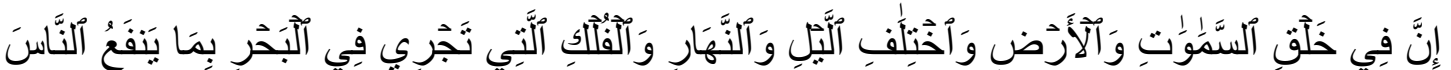

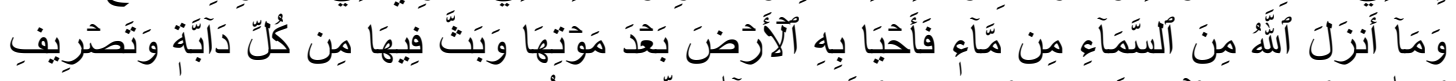

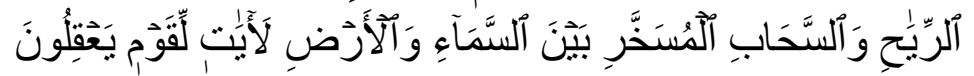

Artinya: "Sesungguhnya dalam penciptaan langit dan bumi, silih bergantinya malam dan siang, bahtera yang berlayar di laut membawa apa yang berguna bagi manusia, dan apa yang Allah turunkan dari langit berupa air, lalu dengan air itu Dia hidupkan bumi sesudah mati (kering)-nya dan Dia sebarkan di bumi itu segala jenis hewan, dan pengisaran angin dan awan yang dikendalikan antara langit dan bumi; sungguh (terdapat) tanda-tanda (keesaan dan kebesaran Allah) bagi kaum yang memikirkan". (Q.S. Al-Baqarah Ayat 164) ${ }^{14}$

Sains dalam kaitannya dengan anak usia dini, menitikberatkan pada proses pembelajaran yang sesuai dengan karakteristik belajar anak usia dini. "Science for children is related to the world the can see around them. It is an exciitng part for

${ }^{12}$ Suyadi, Teori Pembelajaran Anak Usia Dini (Bandung: Rosdakarya, 2014),hlm. 33

${ }^{13}$ Jo Ann Brewer, Intorduction to Early Childhood Preschool through Primary (Grades, USA: Allyn and Bacon, 1992),hlm. 321

${ }^{14}$ Al-Quran dan Terjemahan, Surat Al-Baqarah Ayat 164 


\section{Irfani}

ISSN 1907-0969 E ISSN 2442-8272

Volume 16 Nomor 1 Juni 2020

Halaman 9-25

http://journal.iaingorontalo.ac.id/index.php/ir

their lives. Think about the natural world, how cars work, space programs, he wonders of the stars, to name but a few things". ${ }^{15}$ Pernyataan tersebut memiliki makna bahwa sains untuk anak merupakan bagian yang menarik dalam kehidupan anak yang berhubungan dengan dunia sekitarnya, tentang hal-hal sederhana seperti cara mobil bekerja. Karakteristik belajar anak usia dini, belajar sambil bermain merupakan proses yang menyenangkan dan dinikmati anak dan berwujud pertanyaan.

Sains pada anak usia dini adalah sebuah penjelasan tentang proses mencari sebab akibat fenomena yang ditemukan dari pengalamannya baik di dalam maupun di luar sekolah. Hal tersebut senada dengan yang diungkapkan oleh Neuman bahwa "Anak dapat melakukan kegiatan sains dengan baik, dengan menekankan pada proses menemukan dari pada hanya menerima pengetahuan yang sudah ada. ${ }^{16}$ Pendapat ini menjelaskan bahwa inti pembelajaran anak usia dini sains adalah proses menemukan informasi mengenai fenomena di lingkungan sekitar, melalui pengalaman langsung, dan bagaimana anak mampu menggambarkan apa yang ditemukan secara sederhana. Pembelajaran sains untuk anak usia dini sendiri,dinyatakan sebagai :

"Part of the way you can support your child's science education is by letting him or her know that virtually everything has come scientific basis and that it is therefore endlessly fascinating. Part of any science based work is learning to look carefully, to observe what something is like or what happens and then to record those observation. This and science studies". 17

Pernyataan tersebut dapat diartikan bahwa cara dalam meningkatkan pembelajaran sains pada anak adalah dengan membiarkan anak untuk tahu bahwa segala sesuatu yang ada di dunia ini memiliki dasar sains. Untuk itu, bagian dari pembelajaran sains ini adalah belajar mengamati dan mencatat sesuatu yang mereka amati, yang mana kemampuan tersebut menjadi bagian dari dasar penelitian dalam pembelajaran sains. Selain itu, pembelajaran sains pada anak usia dini diajarkan terintegrasi antara materi biologi, fisika, dan kimia sebagai sebuah kesatuan. Hal ini merujuk pada hakikat sains itu sendiri sebagai sebuah ilmu pengetahuan yang

${ }^{15}$ Poly Bird, Help Your Child to learn at Primary School-How to Support Your Child and Improve Their Learning Potentia (UK: Cromwell Press, 2000),hlm. 64

${ }^{16}$ Donald. B. Neuman, Experience in Science for Young Children (New York: Delmar Publisher, Inc, 1978),hlm. 4

${ }^{17}$ Poly Bird, Help Your Child to learn at Primary School-How to Support Your Child and Improve Their Learning Potentia (UK: Cromwell Press, 2000), hlm. 65 


\section{Irfani}

ISSN 1907-0969 E ISSN 2442-8272

Volume 16 Nomor 1 Juni 2020

Halaman 9-25

http://journal.iaingorontalo.ac.id/index.php/ir

didapatkan secara sistematis.

Berdasarkan teori-teori yang telah diuraikan, dapat dideskripsikan bahwa pembelajaran sains pada anak usia dini menekankan proses menemukan dan melakukan percobaan-percobaan sederhana, sebagai refleksi dari temuannya.

\section{Indikator Kemampuan Sains Anak Usia 5-6 Tahun}

Pembelajaran sains yang diberikan kepada anak bertujuan agar kemampuan anak dalam bidang sains menjadi meningkat. Papalia, Olds, dan Feldman mengemukakan bahwa anak pada rentang usia 5-6 tahun sudah mampu untuk memahami sebab akibat dari suatu kejadian dan memiliki kemampuan untuk mengklasifikasi suatu objek. ${ }^{18}$ Pada usia ini anak sudah memiliki kemampuan untuk mengklasifikasikan benda-benda, orang, dan kejadian kedalam kategori yang bermakna, serta memahami sebab akibat.

Hal ini terkait dengan pendapat Dodge, Colker, dan indikator-indikator, pembelajaran dalam sains diantaranya: ${ }^{19}$ (1) mengamati objek dan peristiwa dengan rasa ingin tau, (2) mengenali hubungan sebab akibat, (3) mengklasifikasi objek, (4) menunjukkan kesadaran konsep waktu dan urutan, (5) mengenalkan tentang tanaman dan hewan, (5) mengenalkan konsep mengenai ilmu fisika melalui memasukan bola, katrol dan magnet, dan (6) mengenalkan anak pada konsep mengenai bumi dan lingkungannya melalui memasukkan batu, kerang dan benda lainnya yang berasal dari alam.

\section{Karakteristik Perkembangan Kognitif Anak Usia 5-6 Tahun dalam Kaitannya dengan Belajar Sains}

Indikator pembelajaran sains yang dikemukakan oleh para ahli, terintegrasi dengan karakteristik perkembangan kognitif anak usia 5-6 tahun. Piaget mengemukakan usia 5-6 tahun termasuk pada tahap praoperasional yang berada pada rentang usia 2-7 tahun. Piaget mengemukakan,

"Children's thinking during this stage is egocentric. That is, they think about the world only in relation on themselves. Along with this, the praoperational period is characterized by symbolic thinking" ${ }^{\prime 2}$. Maksud pernyataan ini, anak-anak pada tahap ini berada pada tahap egosentris, mereka berpikir tentang dunia dalam pikiran mereka sendiri.

${ }^{18}$ Diane E . Papalia, Sally Wendkos Olds \& Ruth Duskin Feldman, Human Development (Perkembangan Manusia) Edisi Kesepuluh (Jakarta: Salemba Humanika, 2008), hlm. 337

${ }^{19}$ Diane Trister, Dodge Colker, \& Cate Heroman, Creative Curricullum, (Washington DC: Teaching Stategies, Inc 2002) hlm. 383

${ }^{20}$ Hilda L.Jackman, Early Education Curriculum (USA: Delmar, 2009), hlm. 9 


\section{Irfani}

ISSN 1907-0969 E ISSN 2442-8272

Volume 16 Nomor 1 Juni 2020

Halaman 9-25

http://journal.iaingorontalo.ac.id/index.php/ir

Seiring dengan ini, tahap praoperasional ini dicirikan oleh pemikiran simbolik.Pada tahap praoperasional di rentang usia 2-7 tahun ini anak mulai menunjukkan pemikirannya secara simbolik. Untuk itu, cara yang paling tepat memperkenalkan anak untuk mengeksplorasi alam disekitarnya sebagai hal yang simbolik.

\section{Media Pembelajaran Realia}

\section{Hakikat Media Pembelajaran}

Media memegang peranan yang cukup penting dalam proses pembelajaran, karena media dapat membantu mempermudah atau memperjelas suatu pelajaran sehingga memudahkan anak untuk menyerap apa yang disampaikan guru. Hal ini juga dikuatkan oleh pendapat Leslie J. Briggs yang mengatakan bahwa media pembelajaran merupakan alat untuk memberikan rangsangan bagi peserta didik supaya terjadi proses belajar mengajar. ${ }^{21}$

Pengklasifikasian media dilakukan oleh Anderson. Klasifikasi media menurut Anderson, yaitu sebagai berikut:

Tabel 2.2. Pengklasifikasian Media Pembelajaran Menurut Anderson ${ }^{22}$

\begin{tabular}{|l|l|l|}
\hline No. & \multicolumn{1}{|c|}{ Kelompok media } & \multicolumn{1}{c|}{ Media instruksional } \\
\hline 1 & Audio & $\begin{array}{l}\text { Pita audio (rol atau kaset) } \\
\text { Piringan audio } \\
\text { Radio (rekaman siaran) }\end{array}$ \\
\hline 2 & Cetak & $\begin{array}{l}\text { Buku teks terprogram } \\
\text { Buku pegangan/manual } \\
\text { Buku tugas }\end{array}$ \\
\hline 3 & Audio-cetak & $\begin{array}{l}\text { Buku latihan dilengkapi kaset } \\
\text { Gambar/poster (dilengkapi audio) }\end{array}$ \\
\hline 4 & Proyek visual diam & $\begin{array}{l}\text { Film bingkai (slide) } \\
\text { Film rangkai (berisi pesan verbal) }\end{array}$ \\
\hline 5 & Proyek visual diam dengan audio & $\begin{array}{l}\text { Film bingkai (slide) suara } \\
\text { Film rangkai suara }\end{array}$ \\
\hline 6 & Visual gerak & Film bisu dengan judul (coption) \\
\hline 7 & Visual gerak dengan audio & $\begin{array}{l}\text { Film suara } \\
\text { Video/vcd/dvd }\end{array}$ \\
\hline
\end{tabular}

${ }^{21}$ Dina Indriana, Ragam Alat Bantu Media Pengajaran ( Jogjakarta: Diva Press, 2011),hlm. 14

22 Rusmono, Strategi Pembelajaran Dengan Problem Based Learning Itu Perlu (Bogor: Ghalia Indonesia, 2012),hlm. 213 


\section{Irfani}

ISSN 1907-0969 E ISSN 2442-8272

Volume 16 Nomor 1 Juni 2020

Halaman 9-25

http://journal.iaingorontalo.ac.id/index.php/ir

\begin{tabular}{|l|l|l|}
\hline No. & \multicolumn{1}{|c|}{ Kelompok media } & \multicolumn{1}{c|}{ Media instruksional } \\
\hline 8 & Benda & $\begin{array}{l}\text { Benda nyata } \\
\text { Model tiruan (mock-up) }\end{array}$ \\
\hline 9 & Komputer & $\begin{array}{l}\text { Media berbasis komputer; CAI } \\
\text { (computer assisted instructional) \& CMI } \\
\text { (computer Managed Instructional) }\end{array}$ \\
\hline
\end{tabular}

Anderson mengklasifikasikan media sesuai kelompok dan berdasarkan jenisnya. Benda nyata menjadi salah satu kelompok media yang dapat digunakan dalam proses pembelajaran.

Media pembelajaran diperlukan sebagai pendukung untuk mencapai tujuantujuan pembelajaran yang ingin dicapai, oleh karna itu pemilihan media yang tepat sangat dibutuhkan agar media pembelajaran benar-benar menjadi media yang efektif dan efisien dalam proses belajar. Keterkaitan antara media pembelajaran dengan tujuan, materi, metode, dan kondisi pembelajar, harus menjadi perhatian dan pertimbangan pengajar untuk memilih dan menggunakan media dalam proses pembelajaran dikelas, sehingga media yang digunakan lebih efektif dan efisien untuk mencapai tujuan pembelajaran. ${ }^{23}$ Hal ini bermakna bahwa guru memiliki peran penting dalam menentukan media pembelajaran dengan menentukan kesesuaian antara media dan tujuan pembelajaran, penggunaannya, kesesuaian kualitas dan biaya yang harus disediakan, serta inovasi.

\section{Media Realia}

Media realia berdasarkan pengklasifikasian Anderson, menjadi kelompok media instruksional. "Media realia is a term for real things, concrete objects that are use in classroom to build background knowledge". 24 Pendapat tersebut dapat diartikan bahwa media realia adalah benda-benda nyata yang digunakan di dalam kelas untuk membangun latar belakang pengetahuan. Penggunaan benda-benda di sekitar anak, dapat membangun pengetahuan anak tentang lingkungannya.

Pengalaman langsung yang dirasakan kepada anak akan mempengaruhi proses pembelajaran karena dapat dinikmati anak secara visual. Zaman mengemukakan bahwa media realia merupakan alat bantu visual dalam pendidikan yang memberikan

23 Hujair AH Sanaky, Media Pembelajaran Buku Pegangan Wajib Guru Dan Dosen (Jogjakarta: Kaukaba Dipantara, 2011), hlm. 6

${ }^{24}$ Aj Romizowski, Early Childhood Generalist Standard (London: Koga Page, 2012), hlm. 8 


\section{Irfani}

ISSN 1907-0969 E ISSN 2442-8272

Volume 16 Nomor 1 Juni 2020

Halaman 9-25

http://journal.iaingorontalo.ac.id/index.php/ir

pengalaman langsung kepada anak. ${ }^{25}$ Pengalaman langsung yang diberikan kepada anak akan berdampak positif, mengingat anak mengamati langsung apa yang akan dipelajari. Media realia juga dapat berupa makhluk hidup maupun peristiwa nyata yang ada di kehidupan sehari-hari. Hanafiah dan Suhana, yang menyatakan bahwa realia merupakan perangsang nyata, seperti orang, binatang, benda, atau peristiwa yang diamati peserta didik. ${ }^{26}$ Banyak objek yang dapat dijadikan sebagai media realia sehingga penggunaannya menjadi perangsang nyata, yang bermaksud menyampaikan pesan guru secara langsung.

Penggunaan media realia memiliki manfaat bagi anak maupun guru. Byrd mengemukakan "Realia help provide direct purposeful experience, which is at the bottom of Dale's cone of experience. Therefore they are ideal for introducing students to a new subject. They give real life meaning to otherwise abstracts words". ${ }^{27}$ Pendapat tersebut dapat disimpulkan bahwa media realia membantu memberikan pengalaman langsung kepada anak. Dalam hal ini media realia membantu guru memperjelas makna sebenarnya, dari kata-kata yang bersifat abstrak, ini disebabkan media realia bersifat nyata.

Banyak manfaat yang diperoleh anak dalam penggunaan media realia, tidak hanya dirasakan oleh anak, guru juga dapat memperoleh keuntungan melalui penggunaan media realia. Media realia masih memiliki keuntungan lain, seperti yang diungkapkan oleh Dhieni, yaitu:

Media realia masih memiliki keuntungan lain, seperti yang diungkapkan oleh Dhieni, yaitu: a) mudah didapat. Pada umumnya media realia ini mudah didapatkan karena merupakan benda nyata yang berada dalam lingkungan kehidupan; b) Memberikan informasi yang jelas dan akurat, mengingat realia merupakan benda yang nyata, maka penjelasan atau informasi yang berkaitan dengan benda tersebut menjadi jelas dan lebih akurat ${ }^{28}$.

Berdasarkan beberapa penjelasan mengenai manfaat media realia dalam proses pembelajaran, dapat dideskripsikan bahwa penggunaan media realia dapat

\footnotetext{
${ }^{25}$ Badru Zaman \& Cucu Elyawati, Bahan Ajar Pendidikan Profesi Guru Media Pembelajaran Anak Usia Dini (Bandung : UPI, 2010),hlm. 36

${ }^{26}$ Nanang Hanafiah Dan Cucu Suhana, Konsep Strategi Pembelajaran (Bandung: Refika Aditama, 2010),hlm. 61

${ }^{27}$ Unty Bany Purnama, Penggunaan Media Realia untuk Meningkatkan Kualitas Proses dan Hasil Belajar IPA (Jurnal Surakarta: Universitas Sebelas Maret, 2012),hlm. 2

${ }^{28}$ Nurbiana Dhieni Dkk, Metode Pengembangan Bahasa, (Jakarta: Universitas terbuka 2010 ),hlm. 11.22
} 


\section{Irfani}

ISSN 1907-0969 E ISSN 2442-8272

Volume 16 Nomor 1 Juni 2020

Halaman 9-25

http://journal.iaingorontalo.ac.id/index.php/ir

membantu anak dalam memahami suatu penjelasan guru yang bersifat abstrak, karena disampaikan secara verbal. Media realia unggul dalam akses, sebab mudah didapat dan mampu menyajikan langsung apa yang ingin disampaikan guru dalam proses pembelajaran.

\section{Karakteristik Media Realia}

Media realia dalam proses pembelajaran memiliki karakteristik. Penggunaan media realia tidak hanya terbatas pada benda nyata seutuhnya, melainkan dapat menggunakan benda nyata yang dapat mewakili. Daryanto menyatakan bahwa media realia adalah benda asli baik hidup maupun mati dan dapat pula berwujud sebagai tiruan yang mewakili aslinya. ${ }^{29}$ Menurut pendapat ini, tidak sepenuhnya benda nyata aslinya, melainkan media realia dapat dimodifikasi sesuai dengan kebutuhan pembelajaran. Pendapat ini juga dikuatkan oleh Heinich, yang menyatakan bahwa penggunaan realia juga dapat dimodifikasi, menurut Heinich modifikasi penggunaan realia dalam proses pembelajaran dapat dilakukan dengan tiga cara, yaitu: cutaway/ potongan, specimen/contoh, exhibit/pameran. ${ }^{30}$ Penggunaan media realia dapat dilakuakan dengan tiga cara yaitu berupa potongan, contoh dan pameran.

Penggunaan media dalam bentuk benda asli atau benda tiruan yang dipilih untuk pengajaran dapat disesuaikan dengan kondisi. Menurut Munadi terdapat tiga karakteristik dalam penggunaan media realia, yakni: (1) benda asli yang tidak dimodifikasi (benda sebenarnya), (2) benda asli yang telah dimodifikasi (imitasi/ replika/ tiruan), (3) sampel. ${ }^{31}$ Ketiga macam media realia tersebut digunakan sesuai dengan kondisi kegiatan belajar mengajar di sekolah dan disesuaikan dengan tujuan pembelajaran.

Berdasarkan pemaparan mengenai karakteristik media realia, dapat dideskripsikan bahwa media realia memiliki karakteristik yang berbeda-beda. Media realia tidak hanya terbatas pada benda nyata seutuhnya, melainkan dapat dimodifikasi atau menggunakan benda yang dapat mewakili agar dapat mempermudah pembelajaran dan pengadaan media.

\footnotetext{
${ }^{29}$ Daryanto, Media Pembelajaran (Jogjakarta: Gava Media, 2010),hlm. 29

${ }^{30}$ Hamzah B. Uno, Profesi Kependidikan (Jakarta: Bumi Aksara 2008), hlm. 117-118

${ }^{31}$ Yudi Munadi, Media Pembelajaran (Jakarta: Gaung Persada Press, 2008),hlm. 108
} 


\section{Irfani}

ISSN 1907-0969 E ISSN 2442-8272

Volume 16 Nomor 1 Juni 2020

Halaman 9-25

http://journal.iaingorontalo.ac.id/index.php/ir

\section{Media Realia dalam Pembelajaran Sains Anak Usia 5-6 Tahun}

Media realia merupakan sebuah alat penyalur informasi dalam pembelajaran yang berbentuk objek nyata dan berasal dari lingkungan sekitar anak. Penggunaan media realia pada pembelajaran sains anak akan lebih bermakna, karena anak mendapat pengalaman secara langsung pada pembelajaran sains. Proses pembelajaran sains anak usia 5-6 tahun sebagaimana yang telah dijelaskan secara teoritik mencakup: (1) mengamati objek dan peristiwa dengan rasa ingin tau, (2) mengenali hubungan sebab akibat, (3) mengklasifikasi objek, (4) menunjukkan kesadaran konsep waktu dan urutan, (5) mengenalkan tentang tanaman dan hewan, (5) mengenalkan konsep mengenai ilmu fisika melalui memasukan bola, katrol dan magnet, dan (6) mengenalkan anak pada konsep mengenai bumi dan lingkungannya melalui memasukkan batu, kerang dan benda lainnya yang berasal dari alam.

Keseluruhan proses pembelajaran sains tersebut, adalah bentuk kegiatan yang memerlukan penggunaan media, untuk mendukung proses belajar anak yang sesuai dengan tahapan perkembangannya. Dalam hal ini kegiatan pembelajaran sains anak usia 5-6 tahun berkaitan dengan indikator perkembangan kognitif atau kemampuan berpikir anak usia dini pada tahap pra operasional dengan rentang usia 2-7 Tahun.

Karakteristik tahap pra operasional dapat dijabarkan sebagai berikut: 1) Individu telah mengkombinasikan dan mentransformasikan berbagai informasi, 2) Individu telah mampu mengemukakan alasan-alasan dalam menyatakan ide-ide, 3) Individu telah mengerti adanya hubungan sebab akibat dalam suatu peristiwa konkrit, meskipun logika hubungan sebab akibat belum tepat, 4) Cara berfikir individu bersifat egosentris yang ditandai oleh tingkahlaku. ${ }^{32}$

Berdasarkan karakteristik tersebut, anak-anak tahap pra-operasional memiliki, kemampuan untuk membangun pengetahuannya, dengan mengkombinasikan dan mentransformasikan, mengetahui hubungan sebab akibat, bersifat egosentris dalam banyak hal, mengekspresikan ide dan mendasarkan persepsi terutama pada cara mereka memahami atau melihat benda-benda.

(a) Bentuk dan besarnya media realia atau model perlu diperhatikan agar dapat dilihat oleh pembelajar dikelas. (b) Jangan terlalu banyak memberikan penjelasan; (c) Gunakan media realia atu model untuk maksud tertentu dalam pengajaran; (d) Usahakan agar para pembelajar sebanyak mungkin dapat belajar

${ }^{32}$ Khadijah, Pengembangan Kognitif anak Usia Dini, (IKAPI Medan :Perdana Publishing), h.38 


\section{Irfani}

ISSN 1907-0969 E ISSN 2442-8272

Volume 16 Nomor 1 Juni 2020

Halaman 9-25

http://journal.iaingorontalo.ac.id/index.php/ir

dari media; (e) Media realia hendaknya diintegrasikan dengan alat-alat lain agar pengajaran berhasil; (f) Didalam suatu pelajaran hanya menggunakan media yang terpilh saja; (g) Apabila menggunakan beberapa benda, hendaknya model tersebut satu sama lain berhubungan dan mnghubungkan pelajaran satu dengan pelajaran yang lain. ${ }^{33}$

Pembelajaran sains dengan media realia perlu memperhatikan langkah-langkah berikut; pertama, bentuk dan ukuran media realia perlu diperhatikan sesuai dengan kondisi anak di dalam kelas,keaktifan anak dan jumlah anak penting untuk diperhatikan dalam menentukan ukuran dan jumlah media realia yang digunakan, ; kedua penggunaan dengan penjelasan tidak terlalu panjang, disebabkan anak akan lebih berfokus pada media yang menjadi objek kegiatan pembelajaran, jika menjelaskan terlalu panjang akan memicu suasana yang tidak efektif disebabkan rasa ingin tahu yang besar anak pada media yang dilihat secara langsungr; ketiga prioritas media realia sebagai media dalam pembelajaran, media realia yang digunakan tidak hanya sebatas pengisi waktu. Jika guru mampu menggunakan media realia sebagai media yang mendukung capaian pembelajaran, maka banyak hal yang dapat dieksplorasi melalui media realia; keempat eksplorasi media realia, banyak hal yang didapatkan anak melalui media realia, pengalaman langsung dalam bereksperimen, bermain sensori motor yang secara langsung melibatkan indera, hal ini dapat menimbulkan pertanyaan yang beragam pada guru; Kelima, media pendukung gunakan peralatan lain yang dapat mendukung media realia dalam kegiatan pembelajaran, ketika anak belajar tentang air tentu saja membutuhkan alat pendukung seperti wadah yang besar sebagai penampung; Keenam, Konsistensi usahakan hanya menggunakan satu jenis media realia, karena akan mengganggu konsentrasi anak pada objek yang digunakan, namun; Ketujuh Integrasi bila dibutuhkan media realia lain, maka media realia tersebut saling berhubungan dalam penyampaian materi pembelajaran.

\section{KESIMPULAN}

Media realia dalam pembelajaran sains dapat memudahkan guru menyampaikan materi yang berhubungan dengan kehidupan sehari-hari di lingkungan sekitar anak. Media realia sebagai objek nyata dapat mewakili kemampuan berpikir simbolik pada tahap pra-operasional, dengan demikian guru mampu menjelaskan

\footnotetext{
${ }^{33}$ Hujair AH Sanaky, Media Pembelajaran Buku Pegangan Wajib Guru Dan Dosen (Jogjakarta: Kaukaba Dipantara, 2011) .hlm 117
} 


\section{Irfani}

ISSN 1907-0969 E ISSN 2442-8272

Volume 16 Nomor 1 Juni 2020

Halaman 9-25

http://journal.iaingorontalo.ac.id/index.php/ir

hal-hal yang bersifat abstrak, secara langsung. Penggunaan media realia tidak selamanya menggunaka objek nyata secara utuh, namun juga dapat dimodifikasi. Penyediaan media realia perlu disesuaikan dengan pembelajaran yang akan dipelajari serta perlu mengutamakan konsentrasi dan eksplorasi dari anak hal ini dimaksudkan agar anak dapat memperoleh banyak pengetahuan dari media realia tersebut.

Pembelajaran sains seperti mengamati objek dan peristiwa dengan rasa ingin tahu, dapat diintegrasikan melalui konsep air, dengan media realia utuh seperti,air dan media pendukung wadah, Anak mampu mengenali hubungan sebab akibat tentang fenomena alam seperti banjir dengan membuat media realia tiruan, berupa maket banjir, anak belajar mengklasifikasi objek, dengan menggunakan biscuit atau balok yang berbeda ukuran dan lain sebagainya. Guru dan orang tua dapat dengan mudah menyampaikan informasi, namun membutuhkan kreativitas dan inovasi dalam penggunaanya.

\section{DAFTAR PUSTAKA}

Atur A Carin, and Robert B Sund, Teaching Science Through Discovery, Columbus Ohio: Merryl Publishing Company, 1989

Beneke Sallee \& Michaelene M. Ostrosky, Teachers' Views of the Efficacy of Incorporating the Project Approach Into Classroom Practice with Diverse Learners, Early Childhood Reasearch and Practice, University of Illinois at Urbana-Champaign, 2009

Bird Poly, Help Your Child to learn at Primary School-How to Support Your Child and Improve Their Learning Potentia, UK: Cromwell Press, 2000

Brewer Jo Ann, Intorduction to Early Childhood Preschool through Primary, Grades, USA: Allyn and Bacon, 1992

Coughlin Pamela. A. et,al, Menciptakan Kelas yang Berpusat Pada Anak 3-5 Tahun, Washington DC: Children's Resources International, Inc, 1997

Dhieni Nurbiana Dkk, metode pengembangan bahasa, Jakarta: universitas terbuka, 2010

Daryanto, Media Pembelajaran, Jogjakarta: Gava Media, 2010

Fieldman Jean R., A Survival Guide For The Preschool Teacher, USA : The center for Applied Research In Education, 1991

Hanafiah Nanang Dan Cucu Suhana, Konsep Strategi Pembelajaran, Bandung:

Refika Aditama, 2010 


\section{Irfani}

ISSN 1907-0969 E ISSN 2442-8272

Volume 16 Nomor 1 Juni 2020

Halaman 9-25

http://journal.iaingorontalo.ac.id/index.php/ir

Indriana Dina, Ragam Alat Bantu Media Pengajaran, Jogjakarta: Diva Press, 2011 Jackman Hilda L., Early Education Curriculum, USA: Delmar, 2009

Kemdikbud, Peringkat dan Capaian PISA mengalami Peningkatan, 2016.

https://www.kemdikbud.go.id/main/blog/2016/12/peringkat-dan-capaian-pisaindonesia-mengalami-peningkatan [10 September 2018]

Khadijah, Pengembangan Kognitif anak Usia Dini, IKAPI Medan :Perdana Publishing, 2016

Kementerian Agama RI, Al-Quran Terjemahan dan Penjelasan Ayat Tentang Wanita, diterjemahkan Yayasan Penyelenggara Penerjemah Al-Quran, disempurnakan Lajnah Pentashih Mushaf Al-Quran, Solo:Tiga Serangkai, 2013

Munadi Yudi, Media Pembelajaran, Jakarta: Gaung Persada Press, 2008

Mutiah Diana, Psikologi Bermain Anak Usia Dini , Jakarta: Kencana, 2010

Neuman Donald. B., Experience in Science for Young Children, New York: Delmar Publisher, Inc, 1978

Papalia Diane E ., Sally Wendkos Olds \& Ruth Duskin Feldman, Human Development (Perkembangan Manusia) Edisi Kesepuluh , Jakarta: Salemba Humanika, 2008

Puckett Margaret B. and Deborah Diffilly, Teaching Young Children An Introduction to the Early Childhood Prefession, New York: Thomson Delmar Lerning, 2004

Purnama Unty Bany, Penggunaan Media Realia untuk Meningkatkan Kualitas Proses dan Hasil Belajar IPA, Jurnal Surakarta: Universitas Sebelas Maret, 2012

Romizowski Aj, Early Childhood Generalist Standard, London: Koga Page, 2012

Rusmono, Strategi Pembelajaran Dengan Problem Based Learning Itu Perlu, Bogor: Ghalia Indonesia, 2012

Sanaky Hujair AH, Media Pembelajaran Buku Pegangan Wajib Guru Dan Dosen, Jogjakarta: Kaukaba Dipantara, 2011

Suyadi, Teori Pembelajaran Anak Usia Dini , Bandung: Rosdakarya, 2014

Trister Diane, Dodge Colker, \& Cate Heroman, Creative Curricullum, Washington DC: Teaching Stategies, Inc 2002

Zaman Badru dan Cucu Eliyawati, Bahan Ajar Profesi Guru Media Pembelajaran Anak Usia Dini, FIP:UPI, 2010 